\title{
SEJARAH MASUKNYA HABAIB KE INDRAMAYU
}

\section{Shaleh Afif :}

\author{
Guru SMA-IT Madinatul Ulum
}

Email :Shalehafifreal@gmail.com

\begin{abstract}
Abstrak
Penelitian terkait Sejarah Masuknya Habaib Ke Indramyu yang dilakukan oleh habaib yang berada di Kabupaten Indramayu serta perannya dalam dakwah agama Islam dalam kurun waktu 1998 sampai 2014. Adapun mayoritas habaib yang berada di Nusantara didominasi berasal dari Hadralmaut dan cukup besar penyebarannya, sementara itu penelitian ini lebih khusus hanya membahas habaib di wilayah Indramayu.Penelitian ini dilakukan bertujuan untuk mengetahui Kondisi keagamaan di Indramayu serta sejarah masuknya habaib di Indramayu yang tentunya memiliki beragam kegiatan untuk mensyiarkan dakwah Islam, juga menguatkan keislaman masyarakat di Indramayu.Metode penelitian yang digunakan penulis adalah metode penelitian sejarah, yaitu penelitian yang mempelajari peristiwa atau kejadian masa lampau berdasarkan jejak-jejak yang dihasilkan, melalui empat tahap yaitu: heuristik (pengumpulan sumber), kritik (kritik intern dan kritik ektern), interpretasi, dan historiografi (penulisan sejarah). Penelitian tersebut dapat disimpulkan bahwa: pertama, kondisi keagaman di Indrmayu sama halnya dengan kondisi keagamaan yang lain yaitu memgang teguh agama Hindu-Budha Kedua, komunitas habaib ini datang dari Hadhramaut (Yaman) pada abad ke 18. Awalnya komunitas habaib yang ada di Indramayu masih tergolong komunitas Arab di Cirebon, akan tetapi pada tahun 1872 komunitas Indramayu memisahkan diri dari komunitas Arab Cirebon, dan menyebar ke seluruh daerah di Indramayu. Meskipun komunitas Arab-Indramayu lebih muda daripada komunitas Arab Cirebon, tetapi komunitas Arab di Indramayu lebih berkembang daripada komunitas Arab di Cirebon.
\end{abstract}

Kata kunci : Habib, Dakwah Islam, Ulama, Indramayu

\section{A. Kondisi keagamaan Indramayu}

Kondisi keagamaan di Indramayu sama seperti kondisi keagamaan di tempat lainnya, ada yang menganut aliran animisme, Budha juga Hindu. Adapun pada periode selanjutnya datang para penjajah membawa agama Kristen, mereka pun mendirikan Gereja. Karena ada upaya kristenisasi, maka diperangilah masyarakat
Indramayu yang dimotori oleh para Habaib, dikarenakan pada kehidupan masyarakat Indramayu terindikasi ada kemusrikan dan menyekutukan Allah. Para Habaib sendiri berperan dalam mengislamkan masyarakat Indramayu yang sebelumnya menganut agama Hindu dan Budha, namun kedatangan penjajah ke Indramayu memperparah 
kondisi masyarakat Indramayu yang dapat mengakibatkan lebih banyak kemusyrikan. ${ }^{1}$

Indramayu pada waktu itu sudah ada yang memeluk Islam, akan tetapi mereka belum bisa menjalankan Islam secara kaffah, karena itu para Habaib berupaya untuk semata-mata tadzidull iman, yang merupakan inti dari Habaib dalam melestarikan iman yang sudah Allah berikan, sebab ada orang Islam yang melakukan shalat, dimana ketika melakukan takbiratul ihram yaitu ketika mengucapkan Allahhuakbar, hatinya sudah tidak fokus pada shalat dengan syahadat, kita akan terus diperbaharui dan rasa yang ingin selalu ingat kepada Allah, sebagimana rasulullah bersabda "barang siapa yang mendawamkan kalimat syahadat dalam hidupnya maka Allah akan menempatkan di kuburanya dan menalkilkan." Dan sekaligus terus setiap waktu ini hati kita di murnikan, sebagaiman contoh jika suatu rumah setiap sore dibersihkan, pagi hari pun dibersihkan, tentu untuk duduk juga akan terasa nyaman begitupun untuk rebahan, sama halnya dengan keimanan dan keislaman, pada saat itu akan di pertanyakan Iman dan Islam kita itu, hati kita, pikiran kita yang tadinya masih memusyrikan selain Allah dengan syahadat akan di bersihkan. $^{2}$

\footnotetext{
${ }^{1}$ Habib Abdurahman As-Segaf, Wawancara, tanggal 29 September 2017 di Indramayu.

2 Habib Alwi Aziz, Wawancara, tanggal 30 September 2017, di Indramayu.
}

Habaib datang ke Indramayu dengan bermacam macam mata pencaharian, jika dahulu para habaib yang dari hadralmaut itu ada yang bermata pencaharian berdagang, berjualan, sekaligus dakwah, karena perkembangan zaman sekarang para habaib ini ada yang berbisnis ada juga yang di instansi pemerintah bahkan ada yang freelance. Akan tetapi tentu sambil syiar Islam, karena bagaimanapun itu sudah menjadi amanat dari leluhur habaib. ${ }^{3}$

Sebelum masuknya agama Islam ke Indramayu, rakyat Indramayu beragama Hindu-Budha, kepercayaan Agama Budha adalah berintikan " Tuhan trimurti" yakni Brahma, Wisnu, dan Siwa, dengan sistem kastanya yang terkenal yaitu Brahmana, Kesatria, Wesya dan Paria sedang Agama Budha berintikan kepada kepercayaan bahwasanya hidup ini "Samasara" yakni kepedihan dan penderitaan. Asal mula samasara adalah dari mula jadinya manusia harus melalui jalan itu baik dalam hidupnya yang sekarang, maupun dalam hidupnya sebagai penjelmaan (reinkarrnasi). Kebenaran mengatasi samasara itu harus melenyapkan hawa nafsu. Jalan yang harus di tempuh dalam penghidupan adalah delapan asta atau yang lebih di kenal dengan "asta sila" yaitu sebagai berikut: ${ }^{4}$

${ }^{3}$ Ibid.

4 Dasuki dkk, Sejarah Indramayu, (Indramayu: Pemkab Daerah Tingkat II Indramayu, 1978), Cetakan ke 3, Hlm. 50. 


\section{Jurnal al-Tsaqafa Volume 15, No. 02, Desember 2018}

1. Keyakinan yang lurus

2. Kemauan yang lurus

3. Berbicara yang lurus

4. Perbuatan yang lurus

5. Hidup yang lurus

6. Ingatan yang lurus

7. Pikiran yang lurus

8.Semadi adalah jalan terpendek untuk mengatasi "samsara"5

Akulturasi berbagai kepercayaan dan kebudayaan itu menjelma dalam bentuk agama Sunda-Hindu, dengan demikian maka sistem Religi di Indramayu pada masa silam menyebabkan adanya Brahmana, Wiku dan Pendeta dari berbagai kepercayaan itu. ${ }^{6}$

Secara keseluruhan dari sumber portugis menerangkan bahwa, pada awal abad ke- XVI M penduduk Jawa Barat (Sunda) banyak yang memelihara candi untuk memuja para dewa, para wanitanya serba elok, yang termasuk kalangan bangsawan berkelakuan baik dan menjaga benar-benar kehormatan mereka, kaum wanita jika tidak berhasil di kawinkan dengan pria idaman orang tua mereka untuk menjaga nama baiknya, dimasukan ke dalam mandala khusus untuk kaum wanita (menjadi wiku wanita) apabila suami mereka meninggal, para istri kaum bangsawan biasanya ikut mati sebagai bentuk bela. ${ }^{7}$

\footnotetext{
${ }^{5}$ Dasuki dkk, Sejarah Indramayu.., Hlm. 50.

${ }^{6}$ Ibid.,
}

${ }^{7}$ Dasuki dkk, Sejarah Indramayu.., hlm. 50.
Dalam dialek bahasa Indramayu bale desa di sebut "lebu" bagaimana sejarah lahirnya kata lebu itu kurang begitu jelas namun tidak mustahil jika ada kaitanya dengan kepercayaan rakyat, "lebu" artinya debu atau abu jadi "palebon" sama artinya dengan "perabuan", yaitu tempat penyimpanan abu jenazah yang sudah di bakar menurut kepercayaan Agamanya, berhubungan dengan itu maka "lebu" yang sekarang menjadi balai desa itu dahulunya adalah tempat penyimpanan abu jenazah. ${ }^{8}$

Upaca "Ngunjung" (ziarah ke kuburan di sertai selamatan) yang masih menjadi tradisi di beberapa di beberapa tempat di Indramayu adalah juga manifestasi dari peninggalan kepercayaan masa lalu yang survive dan telah berubah menjadi upacara yang tradisionil yang pantang surut, dahulu kala upaca ngunjung tersebut dinamakan upacara "srada" dan biasanya di lakukan pada bulan rowah, ( rowah berasal dari kata roh atau arwah) di kuburan diadakan selamatan yang di ramaikan dengan beraneka ragam tontonan seperti topeng wayang dan sebagainya, kemudian ketika selamatan di hidangkan, lebih dahulu di bacakan "mantra" oleh seorang wiku, lalu diperciki dengan air kembang yang disebut "toya tirta". 9

\footnotetext{
${ }^{8}$ Ibid.,

${ }^{9}$ Ibid.
} 
Pada tahun 1471 Sunan Gunung Djati datang ke daerah Indramayu (babadan) untuk mengislamkan Ki Gede Babadan, walaupun di daerah tetangga misalnya Cirebon, agama Islam sudah masuk sejak tahun 1415 dengan kehadiran Syekh Dzatu Kahfi sebagai Da'i Mekkah dan di Karawang sudah masuk sejak tahun 1420 dengan kehadiran Syekh Quro dari Campa, namun berhubung tidak ada beritan tentang yang lebih tua dari itu mengenai perkembangan agama Islam di Indramayu. Maka kehadiran Sunan Gunung Djati di Indramayu pada tahun 1471 itu di anggap sebagai awal mula masuknya Islam di Indramayu. Dan orang yang pertama kali memeluk Islam adalah Ki Gede Babadan. Siapa nama Ki Gede Babadan itu tidak begitu jelas sebab sampai sejauh ini tidak ada berita yang menyebutnya. Namun mengingat kedudukan sebagai $\mathrm{Ki}$ Gede, dapatlah di pastikan bahwa dia mempunyai kedudukan penting dalam lingkunganya. Melalui Ki Gede Babadan agama Islam pasti akan berkembang lebih cepat di Indramayu. ${ }^{10}$

Sesudah Ki Gede Babadan masuk Islam, tidak terdengar lagi berita mengenai perkembangan selanjutnya di Indramayu, baru kemudian pada tahun 1513 terdapat berita yang di tulis Tom pieres mengenai

\footnotetext{
${ }^{10}$ Dasuki dkk, Sejarah Indramayu.., hlm. 50.

${ }^{11}$ Ibid.,
}

perkembangan agama Islam di Indramayu. Tom pieres menuliskan sebagai berikut: ${ }^{11}$

" many moors live here, the captain of this healthen, is belongs to the Kingdom of Sunda. The end of the Kingdom is here"

(banyak orang Islam yang tinggal di sini,tetapi syahbandar nya bukan orang Islam. Pelabuhan ini termasuk wilayah kerajaan sunda, di sinilah batas kerajaan sunda.)

Prof Husain mengatakan bahwa Tom Pieres tidak menyebut tempat lain dimana banyak berkumpul orang Islam selain selain pelabuhan Cimanuk. kalau Tom Pieres bahwa Syahbandarnya bukan orang Islam, mudah di mengerti sebab waktu itu pelabuhan cimanuk masih merupakan bagian dari kerajaan pajajaran yang tidak Islam hanya sayangnya Tom Pieres tidak menyebut nama Syahbandar itu, jarak antara waktu 1471 sampai dengan 1513 adalah 42 tahun pantaslah jika selama 42 tahun agama Islam telah berkembang dengan baik. ${ }^{12}$

Bermacam-macam pendapat mengenai Sunan Gunung Djati antara lain sumber babad mengatakan bahwa Sunan Gunung Djati dalah orang berasal dari Mesir, tetapi ada juga yang mengatakan dari Bani Israil. Di lain pihak sumber sejarah mengatakan bahwa Sunan Gunung Djati adalah orang yang berasal dari Samudra Pasai. Penulisan tersebut terdapat dari

${ }^{12}$ Dasuki dkk Sejarah Indramayu..., hlm. 50. 


\section{Jurnal al-Tsaqafa Volume 15, No. 02, Desember 2018}

bangsa Portugis, berdasarkan dari sumber

Portugis itu makan Prof Husain Djadiningrat dalam usahanya meneliti identitas Falatehan sampai kesimpulan bahwasanya Sunan Gunung Djati identik dengan Falatehan. Panglima tentara Demak yang pada tahun 1526 di perintahkan menduduki Banten dan Sunda Kelapa pada tahun 1552 mendirikan kesultanan Cirebon. ${ }^{13}$

Kesimpulan Prof Husain yang di dasarkan kepada pemberitaan bangsa Portugis dan sudah puluhan tahun di ajarkan di sekolah-sekolah itu ternyata tidak mutlak kebenaranya, terutama stelah di temukan sebuah naskah tua yang di tulis oleh pangeran Arya Cirebon pada tahun 1720 dimana jelas-jelas di nyatakan bahwa Sunan Gunung Djati tidak identik dengan Falatehan. $^{14}$

Menurut sumber tersebut Sunan Gunung Djati adalah orang Indonesia ayahnya seorang peranakan Arab bernama Sayyid Abudllah, adapun ibunya adalah Nyi Mas Rara Santang adik Pangeran Walangsungsang Putri Prabu Siliwangi. Menurut sumber babad, ayah Sunan Gunung Djati itu raja Mesir dan Sunan Gunung Djati di lahirkan di Mekah pada tahun 1448 M namanya waktu kecil adalah Syarief Hidayatullah. ${ }^{15}$

\footnotetext{
${ }^{13}$ Ibid.,

14 Ibid.

${ }^{15}$ Ibid.,
}

\section{B. Pengertian Habaib}

Sebagai suatu kehormatan terhadap Rasulullah SAW, dunia Islam juga memberikan sebutan atau gelar bagi khusus kepada anak cucu baginda Muhammad SAW di Mesir, anak cucu Rasulullah yang bersal dari cucu beliau Al-Hassan maupun Al-Husain di sebut Syarif (bentuk jamaknya Asraf). Sedangkan di luar Hijaz sebutan Syarif hanya di peruntukan bagi anak cucu Rasulullah yang bersasal dari Al Hasan dan sebutan Sayyid (bentuk jamaknya Sadah) bagi anak cucu beliau SAW yang berasal dari anak beliau Al Husain. Di dalam bukunya yang berjudul Tuanku Rao, Prof. Dr. Hamka menuliskan bahwa Rasulullah SAW tidak meninggalkan putra lelaki tetapi, putri beliau SAW Siti Fatimah mempunyai dua orang putra dari perkawinanya dengan Ali bin Abi Thalib Rasulullah sangat menyayangi kedua cucunya ini hingga beliau SAW selalu menyebutnya dengan sebutan anaku beliau SAW pernah berkata tentang Hasan, “ anaku ini kelak suatu saat akan mendamaikan dua kelompok yang sedang bertikai ", perkataan ini terbukti ketika beliau menyerahkan kekuasaan yang ada padanya kepada Muawiyyah. Tahun itu kemudian dinamakan tahun berkumpulya kembali, Amul Jama'ah. ${ }^{16}$

\footnotetext{
16 Muhammad Alaydrus bin Ahmad, Jalan nan lurus.., hlm. 19.
} 
Tentang cucu kedua Husain beliau SAW “anaku ini akan menjadi Sayyid (tuan) para pemuda surga kelak" kedua hadis ini Shahih oleh karena itu maka menjadi tradisi orang memberikan gelar "Sayyid" kepada turunan Hasan dan Husain itu di seluruh dunia Islam demi menghormati hadis tersebut. L.W.C Van Den Berg menyebutkan bahwa para Sayyid tersebut mendapatkan gelar Habib ( jamaknya Habaib) dan anak perempuan mereka bergelar Hababah. Gelar ini di hadralmaut mula berlaku pada abad 11 hingga $14 \mathrm{H} .{ }^{17}$

Habib itu julukan atau gelar yang mula-mulanya itu kan Nabi Muhammad jadi ada silsilah itu dari Siti Fatimah, Siti Fatimah kan kawin sama Sayyidina Ali mempunyai anak namanya Hasan Husain kemudian Husainya terbunuh karena fitnah oleh Yazid. Pada saat itu akan di bunuh semua yang ada yang tersisa adalah itu Ali Zaenal Abidin dari Zenal Abidin ini selanjutnya namanya menyambung silsilah pada jalur silsilah nasab Ali bin Abi Thalib yang menikah dengan Siti Fatimah dan mempunyai anak yang bernama Hasan, Husain, dan muhsin, asal mula Hasan itu adalah nama pemberian dari kakeknya yaitu Nabi Muhammad adapun sebelumnya di beri naman oleh Ali bin Abi Thalibnya adalah Haedar yang mempunyai arti harimau yang

\footnotetext{
17 Ibid.,

18 Muhammad Alaydrus bin Ahmad, Jalan nan lurus ..., hlm. 19.
}

masih muda, setelah Hasan ada lahir lagi akan di beri nama haedar kemudian di beri nama lagi kata kakeknya Husain dan setelah Husain lahir lagi hendak di beri nama haedar lagi tapi Nabi Muhammad memberi nama Muhsin oleh karena itu nama itu menjadi populer antara Hasan, Husain, dan Muhsin yang masih terus di gunakan oleh masyarakat umum. ${ }^{18}$

Arti kata Habib berbeda dengan Kholil, seperti gelar Kholil yang di sandang oleh Nabi Ibrahim Kholilullah, Nabi Isa Ruhullah, Nabi Musa Kalimulllah dan Nabi Muhammad Habibullah jika gelar Kholil artinya segala keinginanya akan di kabulkan oleh Allah akan tetapi harus mendermakan dahulu, sampai meminta anaknya juga dalam kisah Nabi Ibrahim yang tidak bukan adalah Nabi Ismail, artinya silahkan mendermakan semua kehendak Allah setelah itu di beri gelar Kholil berbeda dengan Habib kalau Habib langsung pemberian dari Allah, tanpa ada usaha maksimal dari orang tersebut.kemudian nama Habib dewasa ini banyak yang mengunakan akan tetapi dari kalangan Habib sendiri tidak minta di panggih Habib ataupun di panggil Syarif. ${ }^{19}$

Selanjutnya, ada semacam aturan jika seorang Habib menikah dengan Syarifaah atau Perempuan biasa maka Gelar

\footnotetext{
${ }^{19}$ Habib Yusuf Alaydrus, Wawancara, tanggal 30 September 2017, di Indramayu.
} 


\section{Jurnal al-Tsaqafa Volume 15, No. 02, Desember 2018}

Habibnya masih bisa di turunkan akan tetapi jika Syariffah (habib Perempuan) menikah dengan laki-laki yang bukan keturunan dari habib maka gelar habibnya hilang dan dianggap sebagai orang biasa. Jadi intinya, dikatakan bahw Habib jika dinisbahkan kepada bapaknya bukan kepada ibunya, jadi nasab bapaknya yang lebih kuat. ${ }^{20}$

Dalam sumber lain pemberian nama Habaib itu adalah keturunan Rasulullah SAW yang lahir dari Sayyid Hasan dan Sayyid Husain cucunya Nabi Muhammad SAW karena Nabi Muhammad SAW pernah bersabda Qullu nasabun Qoto;i ila nasabi artinya setiap nasab keturunan itu akan terputus kecuali nasabku Hasan Husain itu nasabnya kepada Hasan Husain dan kepada saya,oleh karena itu Habaib itu jalurnya dari Siti Fatimah karena Nabi Muhammad SAW pernah bersabda seperti itu Hasan Husain itu kan cucuku dan Siti Fatimah adalah anakku. $^{21}$

Berbeda dengan pada umumnya biasanya nasab kepada bapak mungkin itu salah satu kekhususan Hasan Husain itu nasabnya ke Siti Fatimah dan kepada Nabi Muhammad Siti Fatimah anak yang di sayangi oleh Nabi Muhammad terutama dalam hal keimananya yang tinggi dan kesabaranya, kemudian juga sahabat Ali bin Abi Thalib juga ada masih jalur kaka tapi

\footnotetext{
${ }^{20}$ Ibid.,

${ }^{21}$ Habib Yusuf Alaydrus, Wawancara, tanggal 30 September 2017, di Indramayu.
}

kaka berbeda maksudnya adalah Abi Tholib itu kakanya Abdullah dalam artian kakanya bapak itu kemudian dari sabda itu nasab dari Sayyid Hasan dan Sayyid Husain di nasabkan ke Fatimah dan kepada Rasulullah awal di beri nama Habib karena itu karena memang dadulu itu Nabi Muhammad mendapat gelar Habib itu pada saat Isra dan Miraj, kala itu Nabi Muhammad mendapat gelar Habib, memang semua Nabi mendapat gelar, gelar untuk Nabi Muhammad adalah Habib mengandung arti kekasih Allah berbeda dengan Nabi ibrahim itu khalilulah. ${ }^{22}$

Dalam makna penggunaan juga jelas berbeda kalau penggunaan kata khalilullah masih umum dan jika penggunaann kata Habib sudah khusus yang bermakna kekasih Allah selanjutnya jika Sayyid Hasan berlokasi di madinah paada saat itu Sayyid Husain hendak menyelesaikan masalah dengan yazid dari muawiyah karena setelah kahlifah ali bin abi thalib yang memimpin kekuasaan islam adalah dari kalangan Muawiyyah pada saat itu juga Sayyidina ali dan muawiyah pecah Sayyidian Ali sendiri dengan muawiyah permasalahan itu terbawa hingga Sayyidina ali turun ke Hasan mauwiyah turun ke yazid seperti ada gejolak permusuhan di masyarakat maksud Sayyid Husain hendak menyelesaikan masalah

22 Ibid., 
dengan yazid di sangka hendak menyerang pihak muawiyah maka yazid memerintah untuk mengepung dan menggepur dan mengikuti sayidina hasan sampai di tanah karbala dan disitu tepatnya di daerah iran sayidina Hasan dan Husain wafat pada saat itu semuanya tewas akan tetapi ada putranya yang paling kecil namanya ali zenal abidin karena masih kecil umur 5 tahun ketika yang lain di bantai dan di bunuh itu di halangi oleh adik sayidina Hasan yaitu Sayyid Husain di tutupi itu dan tidak jadi di bunuh di biarkan dan hijrah ke hadral maut yaman dari situ turunan dari Sayyid Husain dari ali zaenal abidin tumbuh dan berdakwah ke daerah Indonesia dan daerah-daerah lain Sayyid Hasan yang terdapat di madinah saja Habib itu ya artinya keturuna Rasulullah dari Siti Fatimah. ${ }^{23}$

\section{Sejarah Masuknya Habaib Ke}

\section{Indramayu}

Pada abad pertengahan telah terjadi hubungan yang sangat erat antara Arab selatan terutama maskat, teluk persia, dan nusantara dapat di katakan bahwa para navigator dan pedagang Arab lah yang telah memperkenalkan Islam di nusantara yang pertama di negeri aceh kemudain palembang dan pada abad XVIII di pulau jawa, namun

\footnotetext{
${ }^{23}$ Habib Yusuf Alaydrus, Wawancara, tanggal 30 September 2017, di Indramayu.

${ }^{24}$ Den Berg, L.W.C Ven, Le Hadhralmaut Et Led Colonies Arabes Dans L'Archipel Indien (Jakarta: INIL, 1989 ), hlm 67.
}

dimanapun tidak di temuakn peninggalan para nevigator dan para pedagang Arab itu seperti pendirian koloni Arab yang seperti kita lihat ini. Meskipun sebelum abad itu, sejumlah orang Arab telah menetap di pelabuhan-pelabuhan penting. ${ }^{24}$

Sebelum tahun 1859 tidak tersedia data yang jelas mengenai jumlah orang Arab yang bermukim di daerah jajahan belanda. Di dalam catatan statistik resmi mereka di rancukan oleh orang bengali dan orang asing lainya yang beragama Islam. Sejak tahun 1870 pelayaran dengan kapal uap antara timur jauh dan Arab mengalami perkembangan pesat sehingga perpindahan penduduk dari hadralmaut menjadi lebih mudah. Jadi, tahun itulah awal dari masa yang sepernuhnya baru bagi koloni-koloni Arab di Nusantara. Tabel berikut ini memuat hasil sensus khusus dan rinci yang di laksankan pada tahun 1885 di jawa dan madura di bandingkan dengan angka statistik resmi dari tahun 1870 dan 1859 bagi setiap kerisidenan tempat bermukim orang Arab. ${ }^{25}$

Di semenanjung malaka jajahan inggris sensus pertama orang Arab di laksanakan pada tahun 1814 sensus terakhir yang diterbitkan pemerintah kolonial adalah pada tahun $1884 .^{26}$

\footnotetext{
${ }^{25}$ Ibid.,

${ }^{26}$ Ibid.,
} 


\section{Jurnal al-Tsaqafa Volume 15, No. 02, Desember 2018}

Statistik inggris tidak membedakan antara orang Arab yang lahir di Arab dan mereka yang lahir di nusantara. Oleh karenanya tidak mungkin di bandingkan dengan staitistik belanda pada tahun 1885 dari sudut pandang yang mana pun. Di samping itu, tiga pengamatan umum perlu saya kemukakan mengenai angka-angka yang baru saja diberikan : ${ }^{27}$

1. bahwa populasi Arab di kota-kota yang di sebutkan mencakup juga orang Arab yang tinggal di sekitanya.

2. bahwa wanita pribumi yang kawin dengan orang Arab tidak termasuk ke dalamnya

3. bahwa campuran Arab yang tarmasuk hanya yang belum kehilangan kewarganegaraan.

Menurut tabel statistik, saat ini di pulau jawa terdapat enam koloni besar Arab yaitu : di Batavia, Cirebon, Tegal, Pekalongan, Semarang dan Surabaya, di Madura hanya ada satu yaitu di Sumenep koloni-koloni yang lain yang telah menetap harus di anggap sebagai bersatu dengan ke tujuh koloni tersebut di atas. ${ }^{28}$

Koloni Arab di Cirebon juga relatif baru, pada tahun 1845 koloni tersebut menjadi besar sehingga di butuhkan seorang kepala koloni yang akhirnya sekaligus menjadi kepala semua orang Arab yang ada di keresidenan itu. Baru pada tahun 1872

\footnotetext{
${ }^{27}$ Den Berg, L.W.C Ven, Le Hadhralmaut Et Led 28 Ibid.
}

koloni Arab di Indramayu du pisahkan dari koloni Arab Cirebon dan memilih kepala koloni sendiri di Cirebon semula adalah wilayah orang Bengali dan mereka inilah yang membangun Masjid yang sekarang di kenal dengan dengan nama "Masjid Arab" bangunanya cukup luas, namun kurang terpelihara, seperti juga keadaan seluruh wilayah Arab. Jarang sekali di temui rumah yang cantik koloni Arab di Cirebon bahkan miskin satu-satunya orang Arab yang menjadi grosir telah bangkrut beberapa tahun lalu. Di sepanjang jalan hanya terdapat beberapa toko kecil, kotor dan tidak lengkap isinya, dan tak satupun menunjukan kemakmuran pemiliknya seperti yang biasa terlihat di pecinaan. Sebagai orang Arab di Cirebon hidup dari perdagangan dengan pribumi di keresidena itu dan di bagian timur kerisdenan priangan. Yang mengherankan adalah bagaimana mereka berhasil mencari nafkah dari sana, golongan Sayyid sangat sedikit, koloni Arab di Indramayu berciri sama dengan koloni Arab yang di Cirebon, dan merulpakan cabang dari koloni itu, namun sekarang, meskipun umurnya lebih muda, koloni Arab di Indramayu lebih berkembang. ${ }^{29}$

\footnotetext{
${ }^{29}$ Den Berg, L.W.C Ven, Le Hadhralmaut Et Led Colonies Arabes.., hlm 67.
} 
D. Gelombang Kedatangan dan Koloni Hadarim di Indonesia.

\section{Gelombang Pertama}

Sebenarnya kedatangan hadarim ke ke Indonesia sudah berlangsung sejak lama. Sejak abad ke-12 yaitu sejak kedatangan ulama ba'alwi dari marga Shihab ke Siak yang kemudian menjadi Sultan di sanah. Ulama dari nasab bailfagih ke MindanauFilipina : ulama jamal Al-Lail ke Perlis, yang salah satu keturunanya pernah menjadi di pertuan agung kerajaan Malaysia dan sebagainya kehadiran mereka di masyarakat Nusantara di terima dengan tangan terbuka bahkan mendapat tempat yang khusus dalam masyarakat, seperti yang di tulis oleh Van Den Berg. ${ }^{30}$

Pada abad ke 15, waktu berakhirnya kejayaan Kerajaan Majapahit, di Jawa sudah ada penduduk bangsa Arab atau keturunanya. Orang-orang Arab pada masa itu sudah berbaur dengan penduduk setempat bahkan sebagian diantarnya banyak menduduki jabatan tinggi di kerajaan. Dengan kedudukanya itu mereka sudah terikat dengan tata cara pergaulan dan kekerabatan tingkat atas, bahkan banyak petinggi Hindu yang sudah meniru adat istiadat dan kebiasaan orang Arab, yang mereka serap begitu saja karena yakin

\footnotetext{
${ }^{30}$ Majdid Hasan Bahafdullah, Dari Nuh SA sampai Orang Hadhralmaut Di Indonesia (Jakarta : Bania Publishing, 2010), hlm 166.
}

kebiasaan itu berasal dari keturunan Rasulullah SAW. ${ }^{31}$

Menurut ambarak A. Bazher dalam bukunya sejarah masuk dan berkembangnya Islam di Timor Timur “ orang Hadralmaut sudah lebih dulu bermukim di Timor Lestle jauh sebelum kedatangan orang-orang Portugis di sana. Kerena menurut Habib Abdullah Basyweran, rakyat yang menyambut kedatangan kapal kolonialis tersebut pada tahun 1512 di pimpin oleh seorang Hadralmaut bernama Abdullah Bal Afif. $^{32}$

\section{Gelombang Kedua}

Pada awal abad ke 18 terjadi kedatangan orang Hadralmaut gelombang 2, yang terdiri dari marga Assegaf, Al-Habsyi, Al-Hadad, Alaydrus, Al-Athas, Al-Jufri, Syihab, Syahab, Jamalulai, Al-Qodri, Basyaiban, dan Yahya. Pada permualan abad ke 18 dari Hadralmaut tiba di Cirebon Sayyid Abdurahman bin Muhammad Basyaiban yang kemudian menikah dengan putri sultan Cirebon dari pernikahanya tersebut lahir dua orang putra yaitu Sayyid Sulaiman bergelar "Kyai Mas Mojo Agung" dan Sayyid Abdurahim yang bergelar "Kyai Mas" semula keduanya tinggal di Surabaya

\footnotetext{
31 Ibid.,

32 Ibid.,
} 
namun kemudian pindah ke Krapyak Pekalongan. ${ }^{33}$

Seorang putra dari Sayyid Abdurahim bernama Sa'id menikah dengan puteri Raden Adipati Danurejo, pejabat kerajaan Yogyakarta, dari pernikahan itu lahir tiga orang putra yaitu Sayyid Hasyim bin Abdurahim Basyaiban bergelar "Raden Wongso Rejo “ yang kedua Abdullah bin Abdurahim Basyaiban bergelar "Raden", sedangkan yang ketiga Alwi bin Abdurahim Basyaiban yang pada tahun 1813 di angkat menjadi Regen Magelang yang bergelar "Raden Tumenggung Danuningrat I " dan kemudian pada tahun 1820 bergelar "Raden Adipati". ${ }^{34}$

Keturunan Hasyim dan Abdullah tinggal di Yogyakarta dan beberapa di antaranya memangku jabatan penting di kesultanan Yogyakarta pada tahun 1826 putra Raden Tumenggung Danuningrat I, Sayyid Hamdani bin Alwi Basyaiban menggantikan ayahnya sebagai "Raden Magelang" dan bergelar Raden Tumenggung Danu Kusuma Ningrat II pada tahun 1862 beliau di ganti oleh putranya Sayyid Sa'id bin Hamdan Basyaiban yang bergelar putranya raden Tumenggung Danu Kusumoningrat III. ${ }^{35}$

\footnotetext{
${ }^{33}$ Majdid Hasan Bahafdullah, Dari Nuh SA sampai Orang Hadhralmaut Di Indonesia..., hlm 166. ${ }^{34}$ Ibid.,

35 Ibid.,
}

Pada tahun 1879 beliau di ganti putranya Sayyid Ahmad bin Sa'id Basyaiban yang bergelar "Raden Tumenggung Danu Kusumo" yang menunaikan ibadah haji pada tahun $1818 .^{36}$

Sayyid Abdurahman bin Muhammad Basyaiban memilki putra 13 orang,dan yang mempunyai keturunan hanya Sayyid Sulaiman bergelar kyai Mas Mojo Agung. Diantara keturunanya adalah Abdul Muthalib bin Hasan bin Raden Said Danukusumo yang pernah menjadi menteri perhubungan di era Presiden Sukarno. ${ }^{37}$

Di Kerajaan Jambi dan Aceh banyak terdapat keturunan nasab Baraqbah, Al-Jufri dan Jamal Al-Lail yang seiring berjalanya waktu nama nasab ini hilang, karena banyak yang tidak menggunakan lagi. Pendiri kesultanan Siak sendiri adalah Sayyid Ali bin Utsman bin Shihab dan kesultanan Palalawan di dirikan oleh Sayyid Abdurahman bin Ustman bin Shihab. ${ }^{38}$

Sekitar tahun 1457 Sayyid Hasim bin Syekh Abu Bakar dari Johor mendirikan kerjaan Sulu yang setelah bertahta bergelar "Paduka Maulana Mahasari Syarif Sultan Hasyim bin Syekh Abu Bakar” gelar paduka, gelar setempat yang berarti "tuan"

\footnotetext{
${ }^{36}$ Majdid Hasan Bahafdullah, Dari Nuh SA sampai Orang Hadhralmaut Di Indonesia..., hlm 166. ${ }^{37}$ Ibid.,

${ }^{38}$ Ibid.,
} 
sedangkan mahasari bermaksud yang di pertuan. $^{39}$

Tahun 1703 kesultanan Brunei menganugrahkan Sabah Timur kepada kesultanan Sulu, karena telah membantu menumpas pemberontakan di Brunei. Pada tahun yang sama Kesultanan Sulu menghadiahkan pulau Palalawan kepada Sultan Qudarat dari kesultanan Manguindanao sebagai hadiah perkawinan Sultan Qudarat dengan puteri Sulu, dan juga sebagai hadiah persekutuan Manguindanao dengan Sulu. Sultan Qudarat kemudian menyerahkan Palalawan kepada Spanyol. ${ }^{40}$

\section{Gelombang ke Tiga}

Jika pada gelombang kedatangan Pertama dan kedua mayorittas golongan Habaib atau Sayyid, yang missi utamanya dakwah menyebarluaskan agama Islam, maka kedatangan gelombang ketiga, mayoritas non Habaib yang di sebut Ghabil yang lebih banyak bertujan Sosial Ekonomi di samping Agama. Van den berg dalam $L e$ Hadralmaout Et Les Colonies Arabs Dans i”Archipel Indiem (1889), mengatakan bahwa orang Hadralmaut Non Habaib, sudah menetap di pulau Jawa pada tahun 1820. Sekalipun demikian, sebelum tahun 1859 data jumlah Hadharim di Hindia

\footnotetext{
${ }^{39}$ Ibid.,

${ }^{40}$ Majdid Hasan Bahafdullah, Dari Nuh SA sampai ${ }^{41}$ Ibid.
}

Belanda (Indonesia) tidak jelas, karena sering rancu dengan orang benggali ( orang India ) dan orang asing lainya yang beragama Islam. ${ }^{41}$

Tahun 1858 perantau Hadharim di Hindia-Belanda yang semuanya laki-laki tercatat berjumlah 7768 orang 1870 , meningkat akibat berkecambuknya peperangan yang terjadi sejak tahun 1867 , seperti yang terlihat dari jumlah Hadharim yang meningkat menjadi 12.412 orang tempat tinggal mereka pun sudah mulai menyebar sampai ke Indonesia Timur, di Hawa dan Madura 7.495 sisanya 4.917 tinggal di luar kedua pulau itu, tahun 1885 jumlah mereka menjadi 20.501 orang, di jawa dan madura 10.888 dan dan di luar pulau itu berjumalah $9.613 .^{42}$

\section{Gelombang ke Empat}

Peperangan antara kesultanan AlKatsiri dan Al-Quayti yang berlarut-larut di tambah lagi dengan kedatangan Abdat bersudara, menyebabkan jumlah Hadharim yang meninggalkan negerinya meningkat tajam, seperti yang dicatat Mobini Kesheh bahwa pada tahun 1900 jumlah mencapai 27.399 dan tahun 1920 menjadi 44.902. ${ }^{43}$

Tahun 1930 dan tahun-tahun berikutnya, kedatangan Hadharim semakin

\footnotetext{
${ }^{42}$ Ibid.,

${ }^{43}$ Majdid Hasan Bahafdullah, Dari Nuh SA sampai Orang Hadhralmaut Di Indonesia..., hlm 166.
} 


\section{Jurnal al-Tsaqafa Volume 15, No. 02, Desember 2018}

meningkat, akibat kemelut politik dan keamanan yang semakin parah, peperangan yang tidak pernah berujung pangkal, gangguang keamanan oleh Bani Humun dan bergerliya kekuatan Abdat bersaudara. Kemelut itu di perparah oleh penyerbuan pasukan gabungan Inggris. Al-Katsiri dan Al-Quayti yang telah memakan korban 10.000 orang Hadralmaut mati, rusaknya tanah pertanian yang subur, dan hancurnya sendi-sendi kehidupan ekonomi rakyat. ${ }^{44}$

Gejolak ini telah menyebabkan 90.000 dari 256.00 rakyat Hadharlmaut hijrah ke berbagai negeri di dunia Arab, Afrika, Amerika, India, dan yang ke Asia Tenggara yang kebanyakan memilah Indonesia. Seperti dikatakan Mobini Kesheh, orang Hadhralmaut telah meningkat menjadi 71.355 dan menjelah kedatangan tentara jepang di tahun 1942 di perkirakan sudah berjmlah 80.000 orang. Perjalanan dan koloni Hadharim ke Indonesia dan pemukiman pertama hadharim. ${ }^{45}$

Para perantau atau imigran yang berangkat dari tanah airnya dengan kapal layar biasanya berangkat dari pelabuhan Mukalla Ayai Asy Syihr. Setelah singgah di pelabuhan Oman, Bombai, Srilangka untuk mengisi air, menambah perbekalan, memuat penumpang dan barang., mereka kemudian singgah di Aceh. Dari biasanya para imigran

\footnotetext{
${ }^{44}$ Ibid.,
}

${ }^{45}$ Ibid., ini menuju Palembang atau Pontianak. Karena di kedua kota ini banyak kenalan atau kerabat mereka merek yang sudah hidup mapan. ${ }^{46}$

Bagi yang menggunakan kapal uap yaitu sejak di bukanya terusan Suez, dan mulai beroprasi kapal uap yang melayani trayek Eropa-Timur jauh, sejak tahun 1867 mereka berangkat dari Aden dan transit d Singapura. Dari kota jajahan Inggris ini mereka menuju Batavia untuk selanjutnya menyebar ke berbagai koloni yang jumlahnya sudah mencapai 96 buah kota di Jawa dan Indonesia Timur. Sebelum di berlakukanya peraturan pemukiman (Wijken Stelsel) di awal abad-18 kaum Muhajirin ini di tempatkan di pemukiman yang sudah di tentukan Belanda. Di Batavia, mereka di tempatkan di daerah pantai yang berawarawa dengan lingkungan yang tidak sehat seperti di daerah pasar ikan dan Pekojaan bersama-sama dengan etnis Benggali atau Khoja yang sudah terlebih dahulu tinggal di sana. $^{47}$

\section{E. Koloni hadhrami dan politik kependududkan penjajah belanda.}

Setelah wijken stelse dicabut pada akhir abad ke-19 mereka mulai mencari pemukiman baru yang lebih sehat seperti Batavia di daerah Krukut, Tanah Abang,

\footnotetext{
${ }^{46}$ Majdid Hasan Bahafdullah, Dari Nuh SA sampai Orang Hadhralmaut Di Indonesia..., hlm 166. 47 Ibid.,
} 
Meester Cornelis ( Jati Negara) dan Kwitang. Mereka hidup mengelompok membentuk koloni yang sangat sejalan dengan tujuan penjajah Belanda, yaitu memisahkan mereka dengan penduduk pribumi. Pemukiman mereka yang mengelompok itu di topang oleh Indiche Staat Regeling yang membagi penduduk Hinda Belanda menjadi 3 golongan yaitu Europanen (golongan Eropa) Vreemde Oosteringen (Timur Asing, Arab, India dan Cina dan Pribumi atau Inlanders). ${ }^{48}$

Berdasarkan politik kependudukan tersebut koloni yang sudah mencapai jumlah penduduk tertentu, di angkat seorang pemimpin atau kepala Arab yang di beri pangkat kehormatan (Honorer) yang tinggi rendahnya tergantung populasi yang di pimpinya. Mayor untuk populasi yang besar, Kapitein untuk yang sedang, Luitnant untuk mereka populasi yang sedikit, mereka tidak diberi gaji, fungsinya sebagai penghubung antara penduduk dengan penjajah belanda terutama dalam pengendalian dan pengawasan orang-orang Arab sebagai etnis yang tidak disukai. Selain itu juga mereka diberi tugas untuk melaporkan data penduduk secara priodik, melaporkan mutasinya, menyebarluaskan peraturanperaturan baru, membantu para petugas pajak dan sebagainya. ${ }^{49}$

\footnotetext{
${ }^{48}$ Majdid Hasan Bahafdullah, Dari Nuh SA sampai
} Orang Hadhralmaut Di Indonesia..., hlm 166.
Menurut LWC Van Den Berg koloni sudah terbentuk menjelang abad ke 19 Koloni Indramayu pada mulanya koloni Hadharim di Indramayu bergabung dengan koloni hadharim di Cirebon namun karena jumlah penduduknya terus meningkat, maka pada tahun 1872 di pisah dan di tunjuk seorang pemimpin Arab. Di antaranya hadharim yang pernah menjabat sebagai pemimpin Indramayu adalah Syekh ali bin Ambarak bin Doam pangkat Luitnant masa jabatan 31 Oktober 1896 dan Sayyid Hussein bin Abdul Kadir Alaydrus pangkat Luitnant masa jabatan 26 mei 1904. ${ }^{50}$

Jika berbicara mengenai Habaib Habib ali bin yahya yaitu orang Cirebon mempunyai istri orang Wanguk Indramayu Habib ali bin yahya datang ke daerah Haurgelis Indramayu itu pada tahun 1952 bertujuan untuk Syiar saja beliau ini datang ke Indramayu bukan oleh keinginan sendri akan tetapi di perintah oleh gurunya yaitu Habib Umar bin Syekh bin Toha bin Yahya yang belaiu ajarkan itu di Indramayu adalah tentang Syahadat dan ada perkembangan di Indramayu semenjak tahun 1952 dan dalam perjalananya itu tidak mudah seperti perjalana dakwa yang di lakukan oleh daktuk beliau yaitu Rasulillah ketika mensyiarkan agama Islam itu tentunya

${ }^{49}$ Ibid.,

${ }^{50}$ Ibid., 


\section{Jurnal al-Tsaqafa Volume 15, No. 02, Desember 2018}

banyak tantangan dan pada saat itu beliaum maklumi. ${ }^{51}$

Habib Ali bin Yahya datang ke Indramayu masyarakat heran orang Islam banyak bertanya kenapa memakai pakaian serba putih padahal masyarakat Indramayu belum tahu sebenarnya pakaian putih itu yang di anjurkan oleh Rasulullah SAW. kita itu sebagai umatnya hanya belajar mengikuti bukan semata-mata untuk pamer atau apa pakaian putih itu sebenarnya khusus untuk ibadah saja di luar itu tidak di pakai jadi khusus untuk beribadah saja dan berjalan dari 1952 sampai 1996 berjuang dan hasinya dari semenjak itu dari daerah bugel sampai ke daerah Kroya Suka Selamet jamaahnya Istiqomah. $^{52}$

Kedatangan para Habaib juga tidak lain di bawa oleh walisongo kalau kita oleh Habaib-Habaib terdahulu dulu juga ikut berperang melawan penjajah juga untuk sementar itu untuk Indramayu sendiri awal masuknya Indramayu yang bawa Habib muhammad Abudrahman Asegaf yang makamnya ada di desa Sindang Kecamatan Sidang di samping Masjid Madaniah itu makam Habib Abdrahman Asegaf itu salah satu pembwa Islam di indramyu penyebar Islam lalu di ikuti oleh yang lain-lain seprti Habib Umar bin Toha bin Yahya yang

\footnotetext{
${ }^{51}$ Majdid Hasan Bahafdullah, Dari Nuh SA sampai Orang Hadhralmaut Di Indonesia..., hlm 166.

${ }^{52}$ Habib Alwi Aziz, Wawancara, tanggal 30 September 2017, di Indramayu.
}

makamnya ada di RK sini itu datuknya Habib Lutfi kakeknya kakeknya kalau di Indramayu tersebar ke semua kabupaten Indarmayu sampai ke sebrang pulau Biawak di sanah ada makamnya Habib Hasan Alaydrus yang ada di pulau Biawak dan memang kalau kita lihat sejarahnya para Habaib ini datang ke Indonesia lebih banyak di daerah pesisir pesisir dari mulai Jakarta sampai Banyuwangi bahkan sampai ke sebrang pulau Bali di nagara untuk darah Sumatranya di Palembang di Jambi di Aceh. ${ }^{53}$

Jika di Indonesia kurang lebih pada abad 16 ada yang di Jawa Tengah, Jawa Timur dari Samudra Pasai jika di Indramayu kurang lebih 18 tapi jika dari keluarga Ahmad bin Umar bin Abud bin Nasib Barjrei masuk ke Indramayu pada abad 18 abah dari enjit 18 atau 1830 karna kita melihat masjid An-Nur karna masjid ini berdiri 1286 Hijriah dan sekarang 1349 tjadi kurang lebih 127 tahun lalu. ${ }^{54}$

Para Habaib semua berasal kebanyakan dari Yaman atau Hadhralmaut yang pertama datang ke Indonesia yang tujuan pertamanya adalah untuk dakwah sambil menyambung hidup sambil berdagang jika di Indramayu ini ada dua tempat yang pertama di Sabrang Wetan yang yang kedua Sabrang Lor atau di

53 Habib Umar Alaydrus, Wawancara, tanggal 29 September 2017, di Indramayu. ${ }^{54}$ Ibid., 
daerah Sindang ini cakupanya Indramayu kota atau kabupaten kalau Indramayu kota berada di kecamatan Indramayu dan kecamatan sindang kemudian ada keturuan Arab juga di Jatibarang ada juga di Losarang kemudaian ada juga di Kandanghaur dan kemudian ada di Haurgelis di kecamatankecamatan itu banyak orang-orang Arab bermukim ada juga di kecamtan Anjatan ada sedikit tapi yang fokus itu ada di Jatibarang ada di Sindang dan ada juga di daerah Losarang mata pencaharian orang-orang Arab itu mayoritas di daerah Indramayu itu pedagang berdagangnya bermacam-macam ada yang berdagang dengan cara menetap di pasar ada juga yang mentapnya di rumah ada juga yang di kampung-kampung sambil dakwah sambil bawa barang Yarnen sambil berdakwah sampai ke kampung-kampung sampai haurgelis hingga sampai kemanamana. ${ }^{55}$

Para habaib menikah dengan orang pribumi ada juga yang menikah dengan orang Arab lagi, ada yang menikah dengan orang jawa orang sunda bahkan ada yang menikah dengan orang Cina keturunan Arab itu di Indramayu ikut berperang memerangi penjajah berbeda dengan keluarga kita karena satu darah istrinya orang jawa istrinya orang pribumi, para Habaib mereka berjuang di Indramayu mereka tidak

\footnotetext{
${ }^{55}$ Majdid Hasan Bahafdullah, Dari Nuh SA sampai Orang Hadhralmaut Di Indonesia..., hlm 166.
}

berpangku tangan memang ada prioritas tapi kita ikut berjuang banyak seperti agus Salim.

Selain itu juga hadromi itu termasuk kota santri banyak orang alim termasuk imam Ali Zaenal Abidin pernah menjabat sebagai pemimpin ada juga Habib Umar akan tetapi ke Sindang Laut tapi Khusus Dakwah dan berbicaranya masih walayti ngomongnya masih Arab tidak bisa ngomong sunda setalah itu wafat datang lagi Habib Hasyim seolah-olah seperti itu di snih wafat dikirim lagi gitu memang datang para habaib dari sana semua dan gelar gelar itu di berika atas keistimewaan masing-masing kaya bin yahya dulunya waktu masih bayin antara hidup dan mati akhirnya hidup yahhya kalau orang Arab kan gitu seperti kata zamzamzamzamzam akhirnya air zam zam Yahya Yahya di harapkan kehidupanya terus keistimewaanya dimana saja bisa menghidupkan daerah tersebut baik daerah pertanian baik dari segi Agamaya biasanya yahya itu menghidupkan berbeda alaydrus ada yang menyebutkan di bilangan ruus kepala orang yang mengetahui mana yang baik dan mana yang buruk ketika itu kan julukanya ada seorang ulama yang padahal ulama itu menyesetkan kala itu masih kecil masih di gendong oleh ayahnya jadi ceramahnya terlihat seperti benar tapi membelokan akidah dan mengambil sendal ayahnya langsung di lempar orang-orang itu 


\section{Jurnal al-Tsaqafa Volume 15, No. 02, Desember 2018}

sadar seperti hilang pengaruh di hipnotis bahwa omonganya melenceng bukan ulama dalam keteraangan lain alaydrus itu mengandung arti macan orang yang dalam arti keturunan yang berani dan menjadi macan yang bisa menguasai daerah. ${ }^{56}$

\section{PENUTUP}

\section{A. Simpulan}

Dari penelitian ini, bisa disimpulkan bahwa

1. Kedatangan para habaib di Indramayu awalnya bertujuan untuk menyambung hidup dengan cara berdagang, baik itu dengan mempunyai toko di pasar atau membuka toko di rumah masingmasing, dan ada juga yang berkeliling menjual barang dagangannya. Ada hal yang menarik dalam metode berdagang para habaib ini, yaitu dengan metode khas Indramayu "Yarnen", semacam menjual barang dagangannya dengan cara menghutang dan dibayar ketika panen. Para habaib ini datang ke Indramayu dengan berbagai macam jalan, ada yang ditugaskan oleh guru mereka, ada juga yang keinginan sendiri. Walaupun berbeda-beda jalan, namun tetap membawa misi yang sama, yaitu mengislamkan masyarakat Indramayu yang belum Islam dan memberikan pemahaman kepada yang sudah Islam. Sementara itu para habaib ini cenderung membuat pemerintah Hindia-Belanda mengalami ketakutan, karena sering membuat rakyat pribumi mengadakan pemberontakan-pemberontakan. Hal itu membuat pemerintah Hindia-Belanda mengalami Islmaphobia, atau Arabphobia, hal tersebut mendorong pemerintah HindiaBelanda membuat kebijakan membuat komunitas Arab di Indonesia yang bertujuan agar bisa memantau dan mengontrol aktifitas para habaib tersebut. Adapun pada awalnya para habaib yang ada di Indramayu masih tergolong komunitas Arab di Cirebon, akan tetapi pada tahun 1872 komunitas Indramayu memecahkan diri dari komunitas Arab-Cirebon, dan menyebar di seluruh daerah di Indramayu. Meskipun komunitas Arab-Indramayu lebih muda daripada komunitas Arab-Cirebon, tetapi komunittas Arab di Indramayu lebih berkembang daripada komunitas Arab di Cirebon. Sementara itu hubungan antara habib satu dengan habib yang lain sangatlah erat, hal itu dibuktikan ketika ada acara pernikahan habib atau kematian seorang habib dipastikan yang datang adalah dari berbagai kecamatan di Indramayu, ditambah pula para habaib di Indramayu di wadahi oleh organisasi yang bernama "Rabithah

\footnotetext{
${ }^{56}$ Majdid Hasan Bahafdullah, Dari Nuh SA sampai
} Orang Hadhralmaut Di Indonesia..., hlm 166. 
Alwaiyah Indramayu", dibuktikan jika ada acara besar maka yang mengundang adalah dari organisasi Rabithah Alawayiah. Tentunya kedatangan para habaib ke Indramayu ini membawa pengaruh positif, diantaranya masyarakat Indramayu yang dahulunya masih melakukan perbuatan buruk seperti minum-minuman di pinggir jalan sekarang sudah tidak adalagi, dan juga banyak masyarakat Indramayu yang sengaja datang ke majlis taklim yang para habaib pimpin untuk mempelajari Islam.

\section{DAFTAR SUMBER}

\section{Arsip}

Ya Tarim wa Ahluha, 2010, Batam: Majelis Talim Habib Toha

\section{Buku}

A.Sobana Hadjasaputa,dkk, 2003, Cirebon dalam Lima Zaman abad ke 15 hingga pertengahan abad ke 20, Bandung: Dinas Periwisata dan Kebudayaan Provinsi Jawa Barat.

Dadan wildan, 2003, Sunan Gunung Jati antara fiksi dan fakta, Pembumian Islam dengan pendekatan sturuktural dan kultural, Bandung: perum percetakan negara RI.

Dasuki dkk, 1977, Sejarah Indramayu, Indramayu: Pemkab Daerah Tingkat II Indramayu, Cetakan ke 3.

Dudung Abdurahman, 1999, Metode Penelitian Sejarah, Jakarta: PT. Logos Wacana Ilmu.
Hamid Algadri, 1988, Islam dan Keturunan Arab dalam Pemberontakan Melawan Belanda, Bandung : Mizan.

H.M. H Al-Hamid al-Husaini, 2008, Pembahasan Tuntas Perihal Khilafiyah, Bandung: Pustaka Hidayah.

Kuntowijoyo, 2013, Pengantar Ilmu Sejarah, Yogyakarta : Tirta Wacana.

L.W.C Van Den Berg, 1989, Hadramaut dan Koloni Arab di Nusantara, Jakarta : INIS.

Majdid Hasan Bahafdullah, 2010, Dari Nabi Nuh As sampai orang Hadhramaut di Indonesia, menulusuri asal usul Hadharim, Jakarta : Bania Publishing.

Muhsin Basyaiban, 2014, Majelisnya Pencipta Ulama dan Habaib, Bantul: CV. Layar Creativa Mediatama.

Novel bin Muhammad Alaydrus, 2006, Jalan Nan Lurus (Sekilas Pandang Tarekat Bani 'Alawi), Surakarta: Taman Ilmu.

Nurul Zuriah, 2007, Metodologi Penelitian Sosial dan Pendidikan, Jakarta: PT. Bumi aksara.

Sjamsudin,Helius, 2016, Metodologi sejarah, Yogyakarta: Penerbit Ombak, cetakan ketiga.

Sulasman, 2014, Metodologi Penelitian Sejarah, Bandung: Pustaka Setia.

Suratmin,dkk, 2014, Biografi A.R Baswedan (Membangun Bangsa Merajut Keindonesiaan), Jakarta:Kompas.

Ulul Fahmi el-Qendali dkk, 2011, Biografi 45 Habaib Nusantara, Jombang: Darul Hikmah. 
Ustadz Naufal Muhammad al-Aidarus, 2008, Kisah dan Hikmah, Solo: Pustaka Zawiyah.

\section{Koran}

Justus M Van der Kroef, "The Arabs in Indonesia", Majalah, middle east jurnal vol 7 no 3 Summer, 1953.

NU Online, 29 November 2014, “Indramayu Bershalawat".

\section{Karya Tulis}

Agus Permana, dkk, 2016, "Islam di Betawi

(Studi Peran Habaib dalam Islamisasi dan Integrasi Sosial)”, Hasil Penelitian, Bandung: UIN Sunan Gunung Djati.

M. Albar dkk, 2013, "Peran Sosial Habib Dalam Komunitas Sosial (Studi Kasus

Di Majelis Ilmu dan Dzikir ArRaudhah Surakarta)", Jurnal, Surakarta: Universitas Sebelas Maret.

\section{Sumber Lisan}

Habib Salmin, laki-laki, 53 tahun, Habib di Indramayu, Indramayu: Rumah Habib Salmin, 22 april 2017.

Habib Umar, laki-laki, 50 tahun, Habib di Indramayu, Indramayu: Rumah Habib Umar, 8 april 2017.

Habib Alwi, laki-laki, 49 tahun, Habib di Indramayu, Indramayu: Rumah Habib Alwi, 22 April 2017.

Habib Yusuf, laki-laki, 44 tahun, Habib di Indramayu, Indramayu: Rumah Habib Yusuf, 30 september 2017.
Habib Hasyim, laki-laki, 79 tahun Habib di Indramayu, Indramayu: Rumah Habib Hasyim, 30 september 2017.

Habib Hasan, laki-laki, 60 tahun, Habib di Indramayu, Indramayu: Rumah Habib Hasan, 30 september 2017.

Habib Abdurahman Asegaf, laki-laki, 67 tahun, Habib di Indramayu, Indramayu: Rumah Habib Abdurahman Asegaf, 29 september 2017.

Habib Umar Alaydrus, laki-laki, 38 tahun, Habib di Indramayu, Indramayu: Rumah Habib Umar Alaydrus, 29 september 2017.

Habib Ayip, laki-laki, 42 tahun, Habib di Indramayu, Indramayu: Rumah Habib Ayip, 29 September 2017.

\section{Sumber benda}

Almanak pemerintah Belanda tahun 1896

Foto masjdi An-Nur sindang Indramayu

Foto makam Habib Umar di krangkeng Indramayu

Berkas permohonan pengesahan habib

Foto famplet kegiatan Indramayu bershalawat

Foto kegiatan habib Indramayu bershalawat

Foto kegiatan santunan habib 
Manakib Habib Imam Arif Billah

Muhammad bin Abdurahman Syakof

Silsilah Habib Alyidrus

Ratibul Haddad

\section{Sumber Internet}

Majlisittihad.Wordpress.Com Perihal

Dakwah Damai Kaum Habaib Dan Alawiyin

d -Nusantara di publikasikan pada tanggal

26 juni 2017 di akses pada 19 September 2018 pulul 12.22 WIB. 